\title{
GEOCHEMISTRY OF MARINE SEDIMENTS OF THE BRAZILIAN NORTHEASTERN CONTINENTAL SHELF
}

\author{
Fernanda Souza do Nascimento $^{1}$; George Satander Sá Freire ${ }^{2}$ and Brígida Miola ${ }^{3}$ \\ Universidade Federal do Ceará - Laboratório de Geologia Marinha e Aplicada \\ (Campus Universitário do Pici Bloco 912/913, 60455-760 Fortaleza, CE, Brasil)
}

Corresponding author: fernandasn@ufc.br

${ }^{2}$ freire@ufc.br

3bmiola@gmail.com

A B STRACT

\begin{abstract}
The marine sediment samples collected from the northeastern Brazilian continental shelf, at water depths between 20 and $80 \mathrm{~m}$, consisted mainly of sands with an almost total absence of gravel and granules. Medium, coarse and very coarse sand grains are mostly composed of halimeda, lithothamnium, rodoliths and bioclastic sands with a carbonate content varying between 77 and $96 \%$. The chemistry in general shows a decreasing content of $\mathrm{Ca}(86.1 \%)$ $>\mathrm{Si}(6 \%)>\mathrm{Cl}(3.6 \%)>\mathrm{Sr}(0.8 \%)>\mathrm{K}(0.66 \%)>\mathrm{S}(0.62 \%)>\mathrm{Al}(0.6 \%)>\mathrm{Na}(0.55 \%)>$ $\mathrm{Mg}(0.43 \%)>\mathrm{Fe}(0.4 \%)>\mathrm{P}(0.2 \%)>\mathrm{Br}(0.04 \%)$ in the samples. There was no correlation between $\mathrm{CaCO} 3$ and chemical contents and grain size with depth and biocomponents. With the exception of $\mathrm{Sr}$ of marine origin, all other elements $(\mathrm{P}, \mathrm{S}, \mathrm{Br}, \mathrm{Cl}, \mathrm{Fe})$ are of continental origin. The lithothamnium of some offshore samples shows higher $\mathrm{CaCO} 3$ content, while $\mathrm{Mg}$ and $\mathrm{Na}$ are present only in halimedas. Bioclastic sands contain no $\mathrm{Br}$, and silt and clay fractions are rare and characterize samples closer to the coast. These marine bioclastic granulates are of very pure biogenic calcium carbonates and are thus highly to be recommended for economic purposes.
\end{abstract}

\section{RESUMO}

Os granulados marinhos, da Plataforma Continental do nordeste brasileiro, coletados de profundidades entre 20 e $80 \mathrm{~m}$, são predominantemente areias cascalhosas constituídas de halimedas, litotames, rodolitos e areias bioclásticas, cujos teores de carbonatos variam de 77 a $96 \%$. A concentração média geral de elementos químicos na ordem decrescente é Ca $(86.1 \%)>\mathrm{Si}(6 \%)>\mathrm{Cl}(3.6 \%)>\mathrm{Sr}(0.8 \%)>\mathrm{K}(0.66 \%)>\mathrm{S}(0.62 \%)>\mathrm{Al}(0.6 \%)>\mathrm{Na}$ $(0.55 \%)>\mathrm{Mg}(0.43 \%)>\mathrm{Fe}(0.4 \%)>\mathrm{P}(0.2 \%)>\mathrm{Br}(0,04 \%)$, independentemente da profundidade e tipo de bio-componente. Com exceção do $\mathrm{Sr}$, que é de origem marinha, os demais elementos $(\mathrm{P}, \mathrm{S}, \mathrm{Br}, \mathrm{Cl}, \mathrm{Fe}$ ) são de origem continental. Elementos como $\mathrm{Mg}$ e $\mathrm{Na}$ foram restritos às halimedas em apenas duas amostras, enquanto $\mathrm{Br}$ não foi detectado nas areias bioclásticas. Os maiores percentuais de frações finas (silte e argila) foram encontrados em amostras mais próximas à costa. Altas concentraç̃oes de carbonato de cálcio biogênico caracterizam esse depósito que pode ser considerado como recurso mineral marinho de importante valor econômico.

Descriptors: Marine sediments, Biogenic CaCO3, Geochemistry, Continental shelf, Brazil. Descritores: Carbonato de cálcio marinho, Geoquímica, Plataforma continental, Brasil.

\section{INTRODUCTION}

The main mineral products of Ceará are ornamental rocks thanks to their crystalline geology rich in granites and marbles, being the second major Brazilian northeastern state in non-metallic mineral production. Even so, there are still vast economic metallic (e. g. uranium) and non-metallic mineral resources such as the immense amount of marine algal carbonate on the continental shelf with an extension of about 45,000 $\mathrm{km}^{2}$ (FREIRE, 1985; REDE APL MINERAL, 2008).

The algal carbonate deposits represent a very important natural resource practically covering the whole continental shelf with an estimated $2 \mathrm{x}$ $10^{11} \mathrm{t}$ of carbonate biogenic matter, that have as yet been little exploited (COMISSÃO NACIONAL INDEPENDENTE SOBRE OS OCEANOS, 1998). 
The study area, the continental shelf including the coastal banks of the Ceará State, is mostly constituted of coarse-grained carbonates composed of ramified coral algae with considerable occurrences of halimeda, lithothamnium and rodoliths, which are the major components of the sea bottom platform supplying fish and crustaceans with nutrients. These deposits are also characteristic of the Brazilian northeastern marine hard beds covered with biomass rich in marine algae. The carbonate algae are the most important marine organisms producing calcium carbonate and acting in the formation and maintenance of the coral reefs (SALES et al., 1993; FREIRE; CAVALCANTI, 1998).

Carbonate deposits (similar to those of the Brazilian northeastern continental platform) have frequently been exploited for industrial purposes by several countries since the 1960's, mainly being used for acid soil correction. There are some reports from the Brazilian southern coast where carbonate sediments with concentrations of between 50 and $75 \%$ $\mathrm{CaCO} 3$ have been used for cement production, animal nutrients, and in the cellulose industry etc. (MONT'ALVERNE; COUTINHO, 1982; CALLIARI et al., 1999; DE MELO; FURTINI NETO, 2003).

The carbonate deposits of the Ceará platform are of highly important economic potential, however there are still few studies of their geochemical characteristics. The main objective of the present paper is to establish a geochemical data bank for such deposits and to create a scientific base for the proper exploitation of the so-called Exclusive Economic Zone (ZEE). Thus, the present study focused on the total concentrations of carbonate and some chemical elements of the carbonate sediment samples collected along the Brazilian northeastern platform and banks during the years 1998 and 2000 within the REVIZEE project.

This study is also important when one considers the possibility of the intensification of the fossil fuel exploitation activities of PETROBRAS (the Brazilian national oil company) on the Ceará - Rio Grande do Norte continental platform, which could further impact the environment just as has been reported for the Brazilian Campos platform and other oil producing hot spots of the world (STEINHAUER et al., 1994; REZENDE et al., 2002; POZEBON et al., 2005; LACERDA; MARINS, 2006).

\section{Materials And Methods}

\section{Sampling}

The sediment samples analyzed for the present study were obtained during the REVIZEE Program 1995-2000 (COUTINHO, 2005), a national project for the evaluation of the living marine resources of the Brazilian Exclusive Economic Zone (ZEE). Sediment samples were collected with a stainless steel grab and a Van Veen sampler at different water depths ranging between 10 and 100 meters along the coast from the State of Ceará to that of Bahia (Fig. 1). Nineteen samples (from water depths ranging between 20 and $80 \mathrm{~m}$ ) from the several REVIZEE expeditions such as Northeast II, Northeast III and Northeast IV were chosen randomly.

\section{Treatment of Samples}

The samples were processed in accordance with the standard procedures of desalination, dehydration (at $60^{\circ} \mathrm{C}$ during 48 hours), homogenization and quartering. Finally, they were properly stored while awaiting the analyses of particle size distribution, carbonate content and chemical element concentrations.

\section{Laboratory Analysis \\ Grain Size}

The grain size analyses of the samples were performed by using a modification of Folk's method (1974) at the Applied Marine Geology Laboratory of the Federal University of Ceará: $50 \mathrm{~g}$ of the treated sample was wet sieved to obtain fractions finer than $0.062 \mathrm{~mm}$ (silt and clay), which were dehydrated at room temperature. Their clay and silt content was < $25 \%$ of the total weight of the sample, and therefore the fractions $<0.032 \mathrm{~mm}$ were not measured. To hold back the coarser fractions $(>0.062$ $\mathrm{mm}$ ), dry sieving was carried out using a screen set of stainless steel sieves to separate the following coarse fractions: $5.66-4.00 \mathrm{~mm}, 4.00-2.83 \mathrm{~mm}, 2.83-2.00$ $\mathrm{mm}, 2.00-1.41 \mathrm{~mm}, 1.41-1.00 \mathrm{~mm}, 1.00-0.710 \mathrm{~mm}$, 0.710-0.500 mm, $0.500-0.350 \mathrm{~mm}, 0.350-0.250 \mathrm{~mm}$, $0.250-0.177 \mathrm{~mm}, 0.177-0.125 \mathrm{~mm}$ and $<0.88 \mathrm{~mm}$. The grain size classification was based on Larsonneur (1977), using the ANASED software (V. 5.0).

\section{Carbonate Content (\%)}

A modified Bernard calcimeter and the acid leaching method (LAMAS et al., 2005) were used indirectly to obtain the calcium carbonate content by measuring the $\mathrm{CO} 2$ gas volume produced from the reaction of hydrochloric acid with the carbonate of the whole original sample (rich in algae, halimeda, lithothamnium and rodolith nodules and its lithoclastic and bioclastic matrix). First, the volume (Vst) of saltsatured (saturated ?) water displaced by the carbon dioxide gas released from the chemical reaction of the $2 \mathrm{ml} \mathrm{HCl} 10 \%$ with the carbonate in a $0.5 \mathrm{~g}$ standard sample of $99 \% \mathrm{CaCO} 3$ (Cst) was measured. The same procedure was applied to the samples and their 
percentage of calcium carbonate was calculated using the equation: $[\operatorname{csa}(\% \mathrm{CaCO} 3)=($ vsa $\mathrm{x}$ cst $) /$ vst $]$, where csa is the $\mathrm{CaCO} 3$ concentration of the sample, vsa the salt-saturated solution displaced by the carbon dioxide produced from the reaction of the $\mathrm{HCl}$ with the calcium carbonate in the sample, cst is the $\mathrm{CaCO} 3$ standard concentration, and vst the volume of saltsaturated water displaced by the standard sample.

\section{Chemical Composition (\%)}

The concentration of chemical elements was determined by X-ray fluorescence (XRF) with a Rigaku ZSX Mini II XRF spectrometer at the Department of Physics of the UFC. The analysis was performed on the different constituents of 10 subsamples such as the halimeda of the samples Am-36, Am-42, Am-73, Am-101, Am-86, the lithothamnium of the samples Am-93 and Am-113, the rodoliths of the samples Am-92 and Am-94 and the bioclastic sands of the sample Am-109.

For this analysis a Mylar@ film with low absorption characteristics was stretched over about $1.0 \mathrm{~g}$ of the sample powder, and then subjected to the $\mathrm{X}$-ray fluorescence programmed to scan elements from $\mathrm{F}$ to $\mathrm{U}$, according to the suspended powder method as described in the Rigaku ZSX Mini II instruction manual. The chemical elements detected were $\mathrm{Na}$, $\mathrm{Mg}, \mathrm{Al}, \mathrm{Si}, \mathrm{P}, \mathrm{S}, \mathrm{K}, \mathrm{Ca}, \mathrm{Fe}, \mathrm{Br}, \mathrm{Sr}$ and $\mathrm{Cl}$.

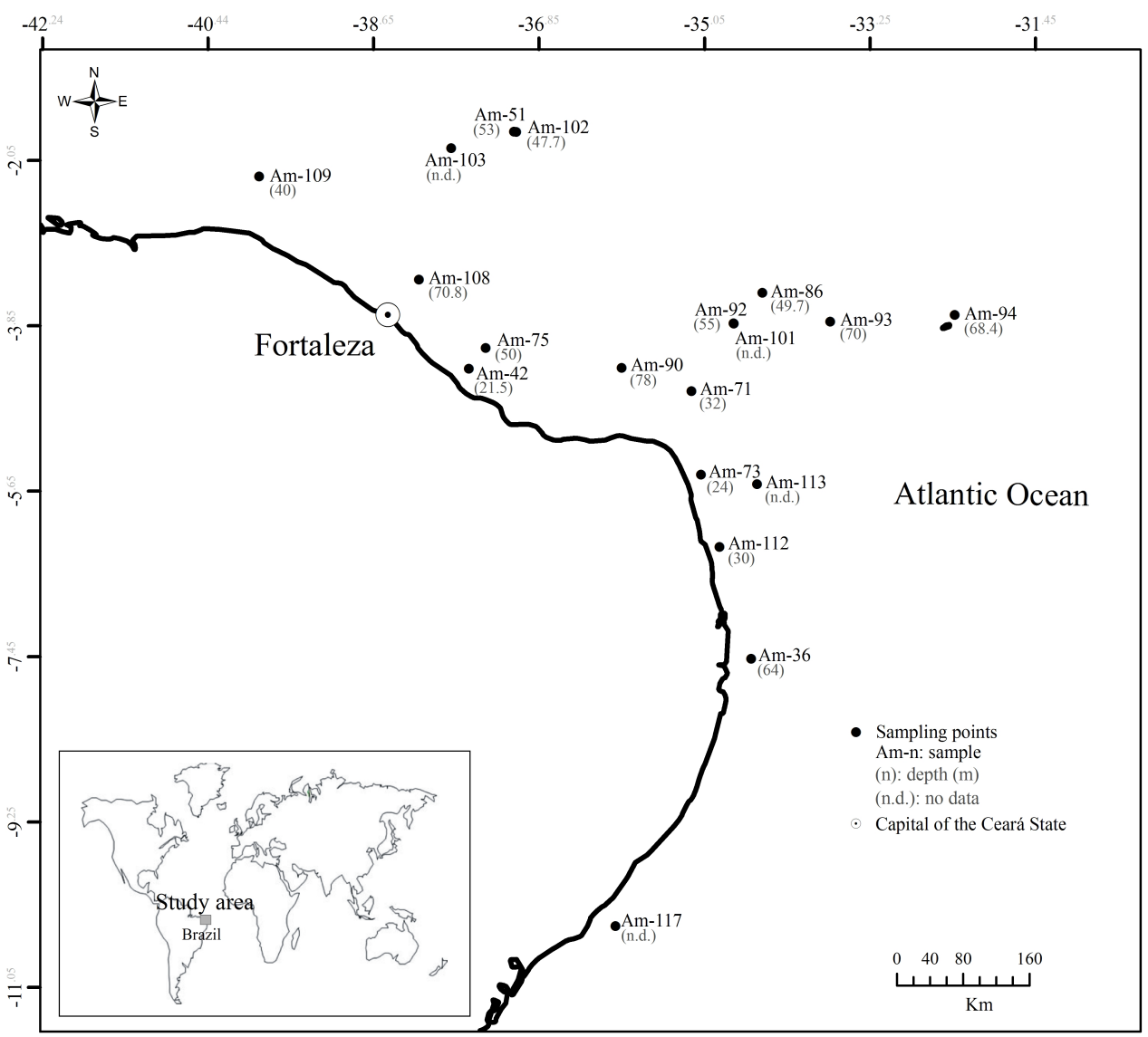

Fig. 1. Location of the sampling stations along the Brazilian Northeastern continental shelf. REVIZEE Program (1995-2000). 


\section{Results \\ Grain-size}

The sediment samples were mostly marine bioclastic sands according to the classification of Larsonneur (1977), with grain sizes varying between sand and gravel. No fine fractions such as silt and clay were determined (Table 1). Generally the samples showing some clay or siltE fraction are located closer to the coastal areas, whereas the samples classified as sandy gravel and gravel after Shepard (1954) are found in offshore locations, sampled at water depths of between 20 and $80 \mathrm{~m}$ and in samples from the coastal banks. They consisted mainly of halimeda and lithothamnium, with some rodoliths, halimeda sands, coralline alga and shell fragments.
Concentration of $\mathrm{CaCO} 3$

The calcium carbonate concentrations of the samples are high, ranging from 77 to $96 \%$, with an average value of $89 \pm 4 \%$. The mean $\mathrm{CaCO} 3$ percentage of each individual sedimentary material varies slightly, decreasing in the following sequence: halimeda $(90 \%)>$ carbonate sand $(89 \%)>$ lithothamnium $(88 \%)>$ halimeda sands $(87 \%)$, (Table 2).

Generally, there is no preferential trend in the distribution of the calcium carbonate content with water depth or kind of bio-constituent, although the higher contents of lithothamnium (Am-92 (91\%), Am-86 (91\%), Am-93 (91\%), Am-94 (91\%) and halimeda (Am-101 (90\%), Am-92 (91\%), Am-86 (92\%), Am-93 (96\%)) appear to be preferentially located offshore (Figs. 2 and 3).

Table 1. Grain size classification of the marine carbonate sediment samples of the Brazilian northeastern continental shelf. REVIZEE Program (1995-2000).

\begin{tabular}{|c|c|c|c|c|c|c|}
\hline \multirow[t]{2}{*}{ SAMPLE } & \multicolumn{3}{|c|}{ GRAIN SIZE (\%) } & \multicolumn{3}{|c|}{ CLASSIFICATION } \\
\hline & Gravel & Sand & Silt and clay & $\begin{array}{l}\text { SHEPARD } \\
\text { (1954) }\end{array}$ & LARSONNEUR (1977) & FREIRE ET AL. (1997) \\
\hline Am-36 & 36.46 & 62.46 & 1.08 & Gravelly sand & $\begin{array}{l}\text { Bioclastic sand with } \\
\text { granules }\end{array}$ & $\begin{array}{l}\text { Bioclastic sand with granules } \\
\text { and gravels }\end{array}$ \\
\hline Am-42 & 16.46 & 83.54 & - & Sand & $\begin{array}{l}\text { Bioclastic sand with } \\
\text { granules }\end{array}$ & $\begin{array}{l}\text { Bioclastic sand with granules } \\
\text { and gravels }\end{array}$ \\
\hline Am-51 & 41.86 & 57.54 & 0.6 & Gravelly sand & Bioclastic sand & $\begin{array}{l}\text { Bioclastic sand with granules } \\
\text { and gravels }\end{array}$ \\
\hline Am-71 & 29.98 & 67.39 & 2.63 & Gravelly sand & Bioclastic sand & $\begin{array}{l}\text { Bioclastic sand with granules } \\
\text { and gravels }\end{array}$ \\
\hline Am-73 & 58.63 & 38.28 & 3.09 & Sandy gravel & Bioclastic granules & Bioclastic gravel \\
\hline Am-75 & 71.56 & 27.13 & 1.31 & Sandy gravel & Bioclastic gravel & Bioclastic gravel \\
\hline Am-86 & 85 & 15 & - & Gravel & Bioclastic gravel & Bioclastic gravel \\
\hline Am-90 & 39.3 & 59.4 & 1.3 & Gravelly sand & Bioclastic sand & $\begin{array}{l}\text { Bioclastic sand with granules } \\
\text { and gravels }\end{array}$ \\
\hline Am-92 & 47.24 & 52.5 & 0.71 & Gravely sand & Bioclastic sand & $\begin{array}{l}\text { Bioclastic sand with granules } \\
\text { and gravels }\end{array}$ \\
\hline Am-93 & 35.24 & 63.9 & 0.86 & Gravelly sand & Bioclastic sand & $\begin{array}{l}\text { Bioclastic sand with granules } \\
\text { and gravels }\end{array}$ \\
\hline Am-94 & 72.49 & 26.82 & 0.69 & Sandy gravel & Bioclastic gravel & Bioclastic gravel \\
\hline Am-101 & 99.9 & 0.1 & - & Gravel & Coquina & Bioclastic gravel \\
\hline Am-102 & 99.9 & 0.1 & - & Gravel & Coquina & Bioclastic gravel \\
\hline Am-103 & 99.9 & 0.1 & - & Gravel & Coquina & Bioclastic gravel \\
\hline Am-108 & 9.61 & 86.91 & 3.48 & Sand & $\begin{array}{l}\text { Coarse to very coarse } \\
\text { bioclastic sand }\end{array}$ & Bioclastic sand \\
\hline Am-109 & 9.98 & 83.7 & 6.32 & Sand & Medium bioclastic sand & Bioclastic sand \\
\hline Am-112 & 28.53 & 63.35 & 8.12 & Gravely sand & Bioclastic sand & $\begin{array}{l}\text { Bioclastic sand with granules } \\
\text { and gravels }\end{array}$ \\
\hline Am-113 & 5.34 & 92.87 & 1.79 & Sand & $\begin{array}{l}\text { Coarse to very coarse } \\
\text { bioclastic sand }\end{array}$ & Bioclastic sand \\
\hline Am-117 & 5.69 & 78.14 & 16.17 & Sand & Clayey bioclastic sand & Bioclastic sand \\
\hline
\end{tabular}


Table 2. Calcium carbonate content $(\%)$ of the marine bioclastic sediment samples of the Brazilian northeastern continental shelf. REVIZEE Program (1995-2000).

\begin{tabular}{|c|c|c|c|c|c|c|c|c|c|c|c|c|c|c|}
\hline \multirow{2}{*}{$\begin{array}{l}\text { CONSTITUENT } \\
\text { Halimeda } \\
\text { (11 samples) }\end{array}$} & \multicolumn{14}{|c|}{ CALCIUM CARBONATE CONTENT (\%) } \\
\hline & $\begin{array}{c}\mathbf{9 6} \\
\text { Am-93 } \\
(70 \mathrm{~m})\end{array}$ & $\begin{array}{c}\mathbf{9 2} \\
\mathbf{A m - 8 6} \\
(497 \mathrm{~m})\end{array}$ & $\begin{array}{c}\mathbf{9 1} \\
\mathrm{Am}-42 \\
(215 \mathrm{~m})\end{array}$ & $\begin{array}{c}91 \\
\text { Am-92 } \\
(55 \mathrm{~m})\end{array}$ & $\underset{\substack{\text { Am-101 } \\
(\mathrm{nd})}}{\mathbf{9 0}}$ & $\begin{array}{c}\mathbf{9 0} \\
\text { Am-90 } \\
(78 \mathrm{~m})\end{array}$ & $\begin{array}{c}90 \\
\text { Am-36 } \\
(64 \mathrm{~m})\end{array}$ & $\begin{array}{c}\mathbf{8 9} \\
\text { Am-73 } \\
(24 \mathrm{~m})\end{array}$ & $\begin{array}{c}\mathbf{8 9} \\
\text { An-112 } \\
(30 \mathrm{~m})\end{array}$ & $\begin{array}{c}\mathbf{8 5} \\
\text { Am-108 } \\
(708 \mathrm{~m})\end{array}$ & $\begin{array}{c}\mathbf{8 5} \\
\text { Am-103 } \\
(\text { nd })\end{array}$ & $\begin{array}{l}90 \pm \\
2.7 \\
2.7\end{array}$ & $\begin{array}{c}96 \\
\text { (MAX) }\end{array}$ & $\begin{array}{c}\mathbf{8 5} \\
\text { (MIN) }\end{array}$ \\
\hline $\begin{array}{l}\text { Lithothamnium nodule } \\
\text { (9 samples) }\end{array}$ & $\begin{array}{c}94 \\
\text { Am-36 } \\
(64 \mathrm{~m})\end{array}$ & $\begin{array}{c}91 \\
\text { Am-86 } \\
(49.7 \mathrm{~m})\end{array}$ & $\begin{array}{c}90 \\
\text { Am-108 } \\
(70.8 \mathrm{~m})\end{array}$ & $\begin{array}{c}\mathbf{8 8} \\
\text { Am-101 } \\
\text { (n.d.) }\end{array}$ & $\begin{array}{c}\mathbf{8 8} \\
\text { Am-103 } \\
\text { (n.d.) }\end{array}$ & $\begin{array}{c}\mathbf{8 8} \\
\text { Am-51 } \\
(53 \mathrm{~m})\end{array}$ & $\begin{array}{c}87 \\
\text { Am-113 } \\
\text { (n.d.) }\end{array}$ & $\begin{array}{c}\mathbf{8 3} \\
\text { Am-71 } \\
(32 \mathrm{~m})\end{array}$ & $\begin{array}{c}\mathbf{8 3} \\
\mathrm{Am}-112 \\
(30 \mathrm{~m})\end{array}$ & $\begin{array}{r}\mathbf{8 8} \pm \mathbf{3 . 5} \\
(\text { MEAN) }\end{array}$ & $\begin{array}{l}\text { (c.a.) } \\
\text { (MAX) }\end{array}$ & $\begin{array}{c}\text { (MEAN) } \\
83 \\
\text { (MIN) }\end{array}$ & & \\
\hline $\begin{array}{l}\text { Bioclastic sand } \\
\text { (7 samples) }\end{array}$ & $\begin{array}{c}95 \\
\text { Am-93 } \\
(70 \mathrm{~m})\end{array}$ & $\begin{array}{c}94 \\
\text { Am-109 } \\
(40 \mathrm{~m})\end{array}$ & $\begin{array}{c}90 \\
\text { Am-90 } \\
(78 \mathrm{~m})\end{array}$ & $\begin{array}{c}86 \\
\text { Am-75 } \\
(50 \mathrm{~m})\end{array}$ & $\begin{array}{c}\mathbf{8 5} \\
\text { Am-94 } \\
(68.4 \mathrm{~m})\end{array}$ & $\begin{array}{c}\mathbf{8 5} \\
\text { Am-108 } \\
(70.8 \mathrm{~m})\end{array}$ & $\begin{array}{c}\mathbf{9 3} \\
\text { Am-117 } \\
\text { (n.d.) }\end{array}$ & $\begin{array}{l}89 \pm \\
4.4 \\
\text { (MEAN) }\end{array}$ & $\begin{array}{c}95 \\
\text { (MAX) }\end{array}$ & $\begin{array}{c}85 \\
\text { (MIN) }\end{array}$ & & & & \\
\hline $\begin{array}{l}\text { Lithothamnium } \\
\text { (5 samples) }\end{array}$ & $\begin{array}{c}93 \\
\text { Am-75 } \\
(50 \mathrm{~m})\end{array}$ & $\begin{array}{c}91 \\
\text { Am-92 } \\
(55 \mathrm{~m})\end{array}$ & $\begin{array}{l}\mathbf{8 8} \\
\mathrm{Am}-73 \\
(24 \mathrm{~m})\end{array}$ & $\begin{array}{c}\mathbf{8 8} \\
\text { Am-117 } \\
(\text { (n.d.) }\end{array}$ & $\begin{array}{c}70 \\
\text { Am-102 } \\
(47.7 \mathrm{~m})\end{array}$ & $\begin{array}{c}86 \pm \\
9.2 \\
\text { (MEAN) }\end{array}$ & $\begin{array}{c}93 \\
\text { (MAX) }\end{array}$ & $\begin{array}{c}70 \\
\text { (MIN) }\end{array}$ & & & & & & \\
\hline $\begin{array}{l}\text { Halimeda sand and gravel } \\
\text { (3 samples) }\end{array}$ & $\begin{array}{c}91 \\
\begin{array}{c}91 \\
\text { Am-86 } \\
(49.7 \mathrm{~m})\end{array}\end{array}$ & $\begin{array}{c}91 \\
\begin{array}{c}91 \\
\text { Am-42 } \\
(21.5 \mathrm{~m})\end{array}\end{array}$ & $\begin{array}{c}77 \\
\mathrm{Am}-71 \\
(32 \mathrm{~m})\end{array}$ & $\begin{array}{c}86 \pm \\
8.1 \\
(\text { MEAN) }\end{array}$ & $\begin{array}{c}91 \\
\text { (MAX) }\end{array}$ & $\begin{array}{l}77 \\
\text { (MIN) }\end{array}$ & & & & & & & & \\
\hline $\begin{array}{l}\text { Rodolith nodule } \\
\text { (2 samples) }\end{array}$ & $\begin{array}{c}94 \\
\text { Am-92 } \\
(55 \mathrm{~m})\end{array}$ & $\begin{array}{c}72 \\
\text { Am-102 } \\
(477.7 \mathrm{~m})\end{array}$ & $\begin{array}{l}83 \pm 16 \\
\text { (MEAN) }\end{array}$ & $\underset{\text { (MAX) }}{91}$ & $\begin{array}{c}72 \\
\text { (MIN) }\end{array}$ & & & & & & & & & \\
\hline $\begin{array}{l}\text { Lithothamnium and shell } \\
\text { fragments } \\
\text { (2 samples) }\end{array}$ & $\begin{array}{c}91 \\
\text { Am-94 } \\
(68.4 \mathrm{~m})\end{array}$ & $\begin{array}{c}\mathbf{8 8} \\
\text { Am-109 } \\
(40 \mathrm{~m})\end{array}$ & $\begin{array}{c}89 \pm \\
2.1 \\
(\text { MEAN) }\end{array}$ & $\begin{array}{c}91 \\
\text { (MAX) }\end{array}$ & $\begin{array}{c}88 \\
\text { (MIN) }\end{array}$ & & & & & & & & & \\
\hline $\begin{array}{l}\text { Lithothamnium nodule, } \\
\text { rodoliths } \\
\text { (2 samples) }\end{array}$ & $\underset{\substack{\text { Am-90 } \\
(78 \mathrm{~m})}}{\mathbf{8 6}}$ & $\begin{array}{c}\mathbf{8 3} \\
\text { Am-75 } \\
(50 \mathrm{~m})\end{array}$ & $\begin{array}{c}84 \pm \\
2.1 \\
(\text { MEAN) }\end{array}$ & $\underset{(\mathrm{MAX})}{86}$ & $\begin{array}{c}83 \\
\text { (MIN) }\end{array}$ & & & & & & & & & \\
\hline $\begin{array}{l}\text { Lithothamnium nodules and } \\
\text { foraminifers } \\
\text { (1 sample) }\end{array}$ & $\begin{array}{c}91 \\
\text { Am-93 } \\
(70 \mathrm{~m})\end{array}$ & & & & & & & & & & & & & \\
\hline $\begin{array}{l}\text { Halimeda sand and gravel, } \\
\text { corals } \\
\text { (1 sample) }\end{array}$ & $\begin{array}{c}\mathbf{8 7} \\
\mathrm{Am}-51 \\
(53 \mathrm{~m})\end{array}$ & & & & & & & & & & & & & \\
\hline Total of samples: 43 & & & & & & & & & & & & & & \\
\hline
\end{tabular}

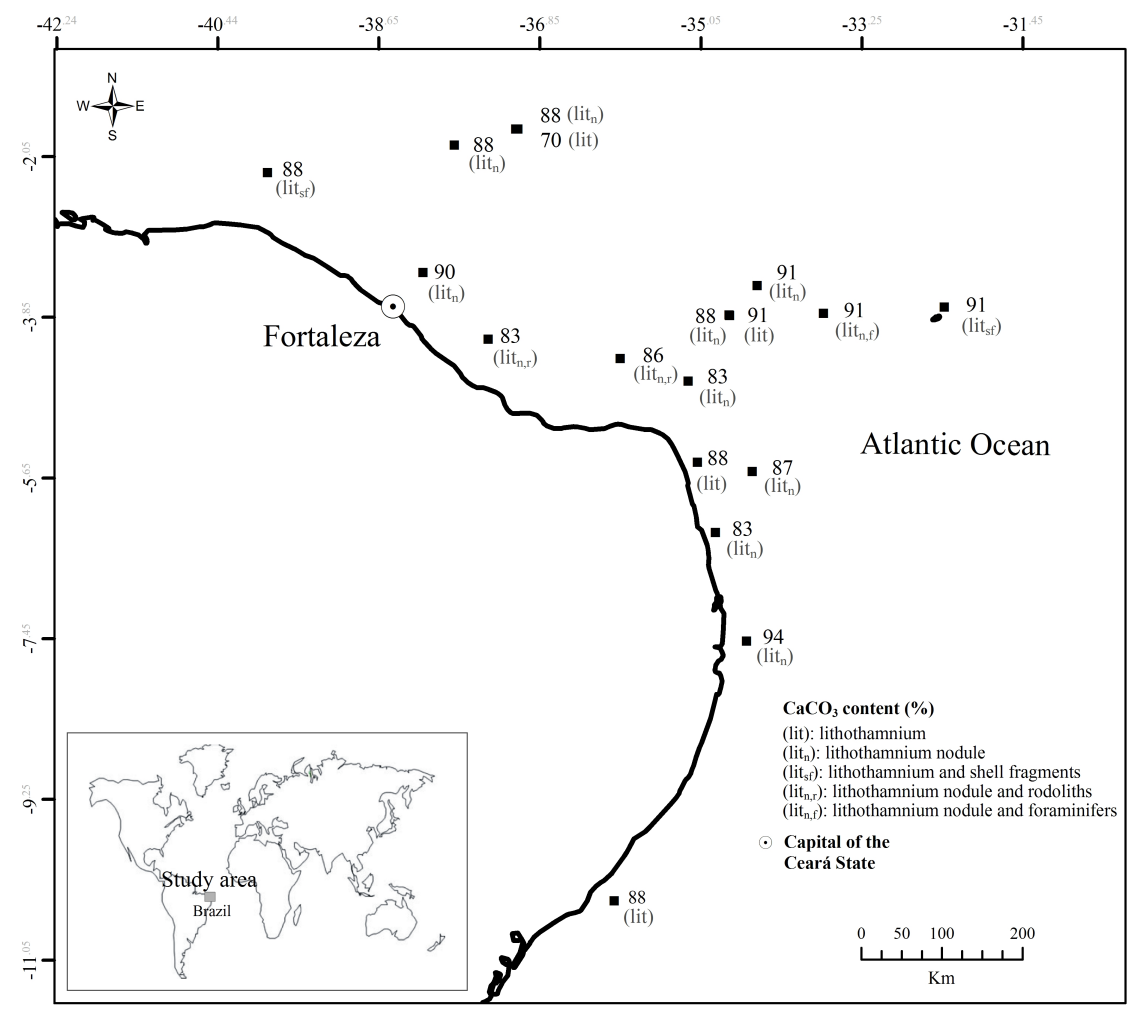

Fig. 2. Calcium carbonate content $(\%)$ in lithothamnium of the marine carbonate sediment samples of the Brazilian Northeastern continental shelf. REVIZEE Program (1995-2000). 


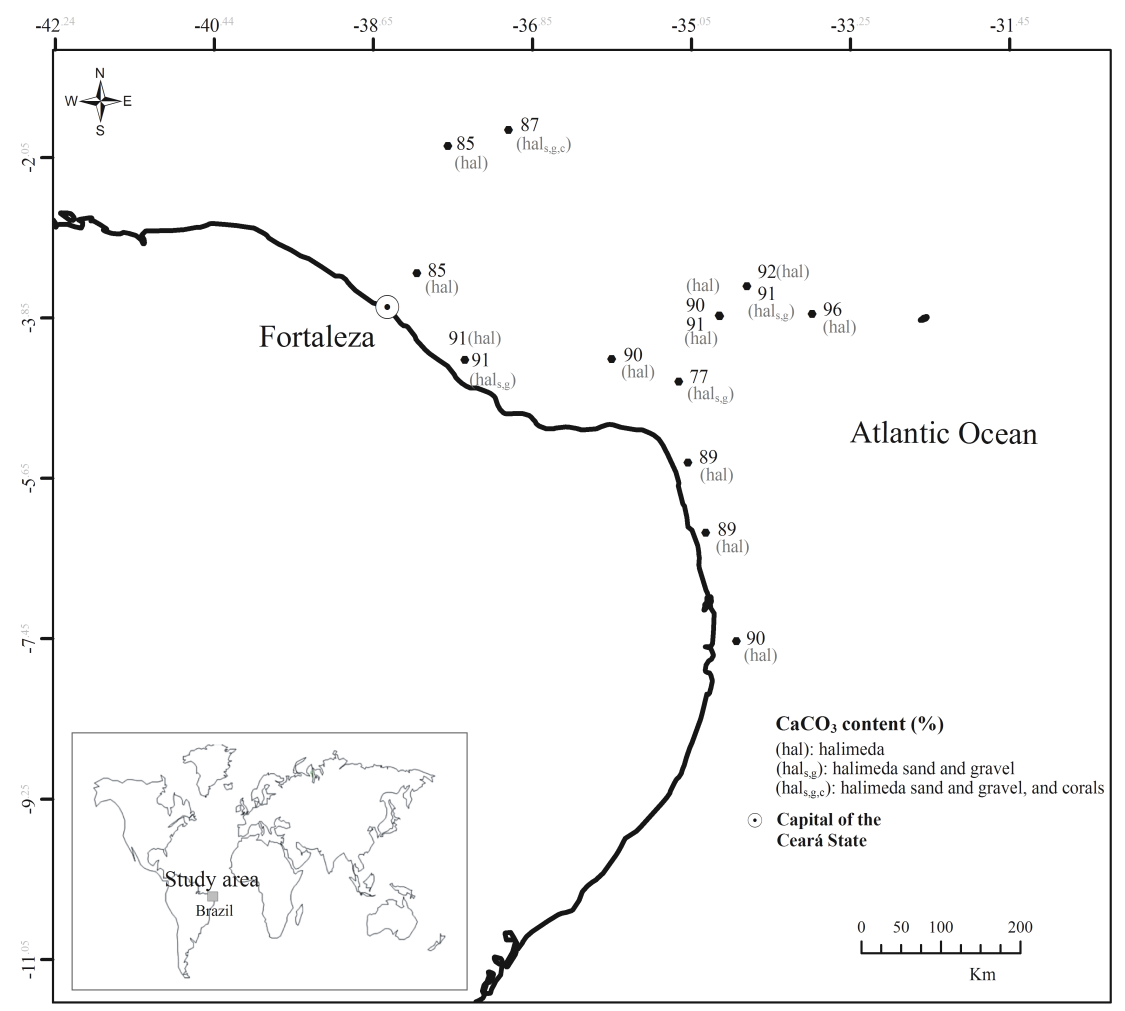

Fig. 3. Calcium carbonate content (\%) in halimeda of the marine carbonate sediment samples of the Brazilian Northeastern continental shelf. REVIZEE Program (1995-2000).

Taking the carbonate concentrations into account those sediments were reclassified as bioclastic sands (80\% of the total samples), varying between bioclastic sand and bioclastic sand with granules and gravels. The rest $(20 \%$ of the total samples) were classified as bioclastic gravels, according to Freire et al. (1997, adapted from Larsonneur, 1977) who considers the carbonate content in its grain size sediment classification).

\section{Concentration of Chemical Elements}

Table 3 shows the chemical element concentrations of the different constituents of the samples. With some exceptions $(\mathrm{Na}, \mathrm{Mg}, \mathrm{Br})$ all the elements $\mathrm{Mg}, \mathrm{Al}, \mathrm{Si}, \mathrm{P}, \mathrm{S}, \mathrm{K}, \mathrm{Ca}, \mathrm{Fe}, \mathrm{Br}, \mathrm{Sr}, \mathrm{Cl}$ were detected in all samples.

As expected, the most abundant element was $\mathrm{Ca}$. The mean $\mathrm{Ca}$ concentration of the constituents ranged from $83 \%$ to $93 \%$, decreasing in the following order: bioclastic sand $(94 \% \mathrm{Ca})>$ rodoliths $(88 \% \mathrm{Ca})$ $>$ halimeda and halimeda flour $(85 \% \mathrm{Ca})>$ lithothamnium ( $83 \% \mathrm{Ca})$.

The $\mathrm{Si}$ concentrations also varied widely, from $2.0 \%$ to $11 \%$ in the following decreasing sequence: lithothamnium $(11 \% \mathrm{Si})>$ halimeda and halimeda flour $(6.0 \% \mathrm{Si})>$ rodoliths $(4.0 \% \mathrm{Si})>$ bioclastic sand $(1.0 \% \mathrm{Si})$. Chlorine showed a median abundance with a mean concentration of $3.0 \% \mathrm{Cl}$, whereas $\mathrm{Sr}, \mathrm{Al}, \mathrm{K}, \mathrm{S}, \mathrm{Fe}, \mathrm{P}$ and $\mathrm{Br}$ represent the less abundant elements (mean concentration $<1.0 \%$ ).

Sodium was only detected in two samples of the halimeda from depths of about $50 \mathrm{~m}$ on the offshore platform (Am-51 and Am-101) and these contained $\mathrm{Fe}$ and $\mathrm{Al}$ at or below detection limits although both elements were almost always present in all the sample components. The highest $\mathrm{Fe}$ concentration $(2.32 \% \mathrm{Fe})$ was found in the rodoliths of the sample (Am-92; $49.7 \mathrm{~m})$ similar to that of the already mentioned halimeda sample (Am-101; $50 \mathrm{~m})$ without $\mathrm{Fe}$ and $\mathrm{Al}$. The bioclastic sand sample (Am$109 ; 40 \mathrm{~m}$ ) of the most northerly part of the study area showed the lowest $\mathrm{Fe}$ concentration $(0.11 \% \mathrm{Fe})$, being the only sample without $\mathrm{Br}$ in its chemical 
composition, whereas there is a restricted occurrence of $\mathrm{Mg}$ in the halimeda sample $(\mathrm{Am}-36 ; 70 \mathrm{~m})$ of the southern part of the area. Finally, the mean relative percentages of these elements decreases in the following order: $\mathrm{Ca}(86.1 \%)>\mathrm{Si}(6 \%)>\mathrm{Cl}(3.6 \%)$

$>\mathrm{Sr}(0.8 \%)>\mathrm{K}(0.66 \%)>\mathrm{S}(0.62 \%)>\mathrm{Al}(0.6 \%)>$

$\mathrm{Na}(0.55 \%)>\mathrm{Mg}(0.43 \%)>\mathrm{Fe}(0.4 \%)>\mathrm{P}(0.2 \%)$

$>\operatorname{Br}(0.04 \%)$ (Fig. 4).

Table 3. Chemical composition of the marine carbonate sediment samples of the Brazilian northeastern continental shelf. REVIZEE Program (1995-2000).

\begin{tabular}{|c|c|c|c|c|c|c|c|c|c|c|c|c|c|}
\hline \multirow{2}{*}{$\begin{array}{l}\text { CONSTITUENT } \\
\text { Halimeda }\end{array}$} & \multicolumn{13}{|c|}{ CHEMICAL COMPOSITION (\%) } \\
\hline & $\mathrm{Ca}$ & Si & $\mathbf{C l}$ & $\mathbf{F e}$ & Al & $\mathbf{S}$ & $\mathbf{K}$ & $\mathrm{Sr}$ & $\mathbf{P}$ & Br & Mg & $\mathbf{N a}$ & Total \\
\hline Am-36 & 83 & 7.86 & 1.96 & 0.19 & 0.59 & 0.43 & 0.42 & 0.68 & 0.17 & n.d. & 4.28 & n.d. & 100 \\
\hline Am-42 & 90 & 1.36 & 5.74 & 0.19 & 0.30 & 0.49 & 0.30 & 1.45 & 0.13 & 0.04 & n.d. & n.d. & 100 \\
\hline Am-73 & 93 & 0.89 & 3.95 & 0.14 & 0.40 & 0.41 & 0.64 & 0.61 & 0.19 & 0.04 & n.d. & n.d. & 100 \\
\hline Am-101 & 92 & 0.41 & 2.18 & n.d. & n.d. & 0.61 & 0.29 & 0.96 & 0.14 & 0.03 & n.d. & 3.02 & 100 \\
\hline Am-86 & 67 & 19 & 7.59 & n.d. & n.d. & 1.54 & 1.17 & 0.37 & 0.42 & 0.14 & n.d. & 2.45 & 100 \\
\hline Mean & 85.12 & 5.95 & 4.28 & 0.10 & 0.26 & 0.70 & 0.56 & 0.81 & 0.21 & 0.05 & 0.86 & 1.09 & 100 \\
\hline \multicolumn{14}{|l|}{ Rodoliths } \\
\hline Am-92 & 86 & 5.37 & 2.25 & 2.32 & 2.12 & 0.52 & 0.80 & 0.68 & 0.16 & n.d. & n.d. & n.d. & 100 \\
\hline Am-94 & 90 & 2.31 & 4.14 & 0.39 & 0.29 & 0.73 & 0.85 & 0.59 & 0.26 & 0.06 & n.d. & n.d. & 100 \\
\hline Mean & 88.07 & 3.84 & 3.20 & 1.36 & 1.21 & 0.63 & 0.82 & 0.64 & 0.21 & 0.03 & & & 100 \\
\hline \multicolumn{14}{|l|}{ Bioclastic sands } \\
\hline Am-109 & 94 & 1.14 & 2.30 & 0.11 & 0.30 & 0.43 & 0.24 & 0.95 & 0.18 & n.d. & n.d. & n.d. & 100 \\
\hline \multicolumn{14}{|l|}{ Lithothamnium } \\
\hline Am-93 & 96 & 0.51 & 1.44 & n.d. & 0.19 & 0.48 & 0.20 & 0.84 & 0.18 & 0.05 & n.d. & n.d. & 100 \\
\hline Am-113 & 70 & 21 & 4.25 & 0.63 & 1.49 & 0.55 & 1.66 & 0.43 & 0.20 & n.d. & n.d. & n.d. & 100 \\
\hline Mean & 82.91 & 10.8 & 2.84 & 0.32 & 0.84 & 0.51 & 0.93 & 0.64 & 0.19 & 0.02 & & & 100 \\
\hline
\end{tabular}

n.d.: no detected
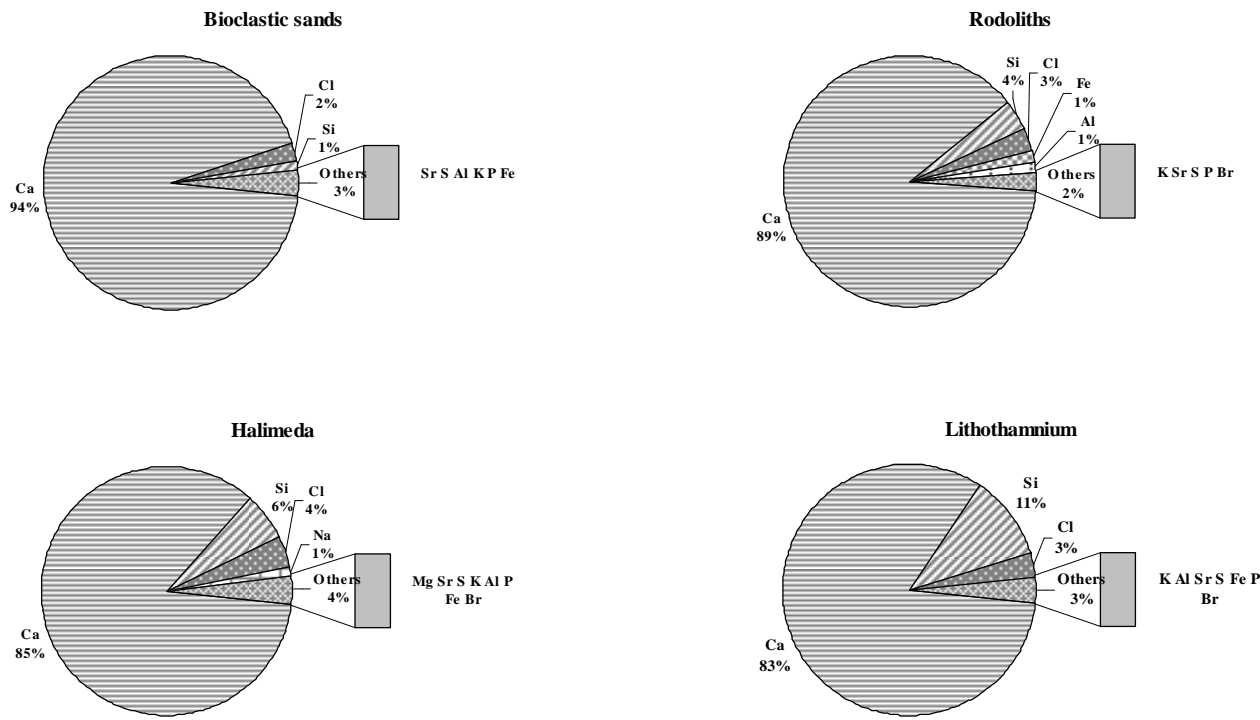

Fig. 4. Relative distribution of chemical elements in the marine carbonate sediment samples of the Brazilian northeastern continental shelf, REVIZEE Program (1995-2000). 


\section{Pearson Correlation Coefficients}

The Pearson correlation coefficients were calculated among the concentrations of $\mathrm{K}, \mathrm{Ca}, \mathrm{Sr}, \mathrm{Fe}$, $\mathrm{Al}, \mathrm{Si}, \mathrm{P}, \mathrm{S}, \mathrm{Cl}$ and $\mathrm{Br}$. There is no correlation coefficient data for $\mathrm{Na}$ and $\mathrm{Mg}$ because they were detected in one or two samples only (Table 4).

\section{DisCUSSION}

The northeastern Brazilian continental shelf of Ceará can be divided into offshore and inshore platform sectors, where most of the sampling stations were located representing the organogenesis facies of Freire (1985) and Freire et al. (2004).

The dominantly biogenic composition of the offshore platform sediments is due to a combination of various factors such as the semi-arid equatorial climate, small and sparse fluvial drainage, and relatively low rainfall (mainly during the period from June to December, with an average annual precipitation of around $1,400 \mathrm{~mm}$ ), which all contribute to a low input rate of terrestrial sediments (FREIRE, 1985; SALES et al., 1993; COUTINHO, 1995; FREIRE; CAVALCANTI, 1998).
The essentially biogenic characteristic of the sediments is due to the macroscopical algae components present in all the samples rich in lithothamnium, halimeda, rodoliths, bioclastic sands and shell fragments and to the high calcium carbonate content ranging from 70 to $97 \%$, far above the reference value distinguishing lithoclastic from bioclastic sediments, according to Freire et al. (1997) and Larssoneur (1977).

These bioclastic marine sediments of halimeda, lithothamnium, rodoliths and bioclastic sands are of marine biogenic origin rich in $\mathrm{Ca}(\mathrm{Ca}: 83$ to $94 \%$ ), but poor in $\mathrm{Si}, \mathrm{Al}$ and $\mathrm{K}$ ( $\mathrm{Si}: 0.41 \%$ to $21 \%$, Al: $0.19 \%$ to $2.12 \%$, K: $0.2 \%$ to $1.66 \%$ ) whereby it is to be concluded that the latter contents are derived from the clastic continental sources.

The correlation coefficients $(r> \pm 0.5)$ point to biomarine sources for $\mathrm{Sr}(\mathrm{Ca} / \mathrm{Sr}=0.62, \mathrm{Si} / \mathrm{Sr}=-$ $0.66)$ and land sources for $\mathrm{P}(\mathrm{Ca} / \mathrm{P}=-0.63, \mathrm{Si} / \mathrm{P}=$ $0.60), \mathrm{S}(\mathrm{Ca} / \mathrm{S}=-0.66, \mathrm{Si} / \mathrm{S}=0.58), \mathrm{Br}(\mathrm{Ca} / \mathrm{Br}=-0.97$, $\mathrm{Si} / \mathrm{Br}=0.99)$ and $\mathrm{Cl}(\mathrm{Ca} / \mathrm{Cl}=-0.62, \mathrm{Si} / \mathrm{Cl}=0.53)$. In the case of $\mathrm{Fe}$, with the exception of the correlation $\mathrm{Fe} / \mathrm{Br}(\mathrm{r}=0.99)$ that indicates continental rather than biomarine sources, all the other correlation coefficients obtained were insignificantly low (all $\mathrm{r}<$ \pm 0.32 ) (Fig. 5).

Table 4. Pearson correlation coefficients between the chemical components of the marine carbonate sediment samples of the Brazilian northeastern continental shelf. REVIZEE Program (1995-2000).

\begin{tabular}{llllllllll}
\hline \hline & $\mathbf{K}$ & $\mathbf{C a}$ & $\mathbf{S r}$ & $\mathbf{F e}$ & $\mathbf{A l}$ & $\mathbf{S i}$ & $\mathbf{P}$ & $\mathbf{S}$ & $\mathbf{C l}$ \\
$\mathbf{C a}$ & -0.85 & & & & & & & & \\
$\mathbf{S r}$ & -0.74 & 0.62 & & & & & & & \\
$\mathbf{F e}$ & 0.31 & -0.24 & -0.23 & & & & & & \\
$\mathbf{A l}$ & 0.63 & -0.60 & -0.42 & 0.19 & & & & & \\
$\mathbf{S i}$ & 0.87 & -0.98 & -0.66 & 0.17 & 0.60 & & & & \\
$\mathbf{P}$ & 0.52 & -0.63 & -0.66 & -0.10 & -0.12 & 0.59 & & & \\
$\mathbf{S}$ & 0.45 & -0.66 & -0.46 & 0.19 & 0.10 & 0.58 & 0.93 & & \\
$\mathbf{C l}$ & 0.51 & -0.62 & -0.17 & -0.33 & -0.10 & 0.53 & 0.67 & 0.73 & \\
$\mathbf{B r}$ & 0.83 & -0.97 & -0.62 & 0.99 & -0.32 & 0.99 & 0.95 & 0.97 & 0.75 \\
\hline
\end{tabular}



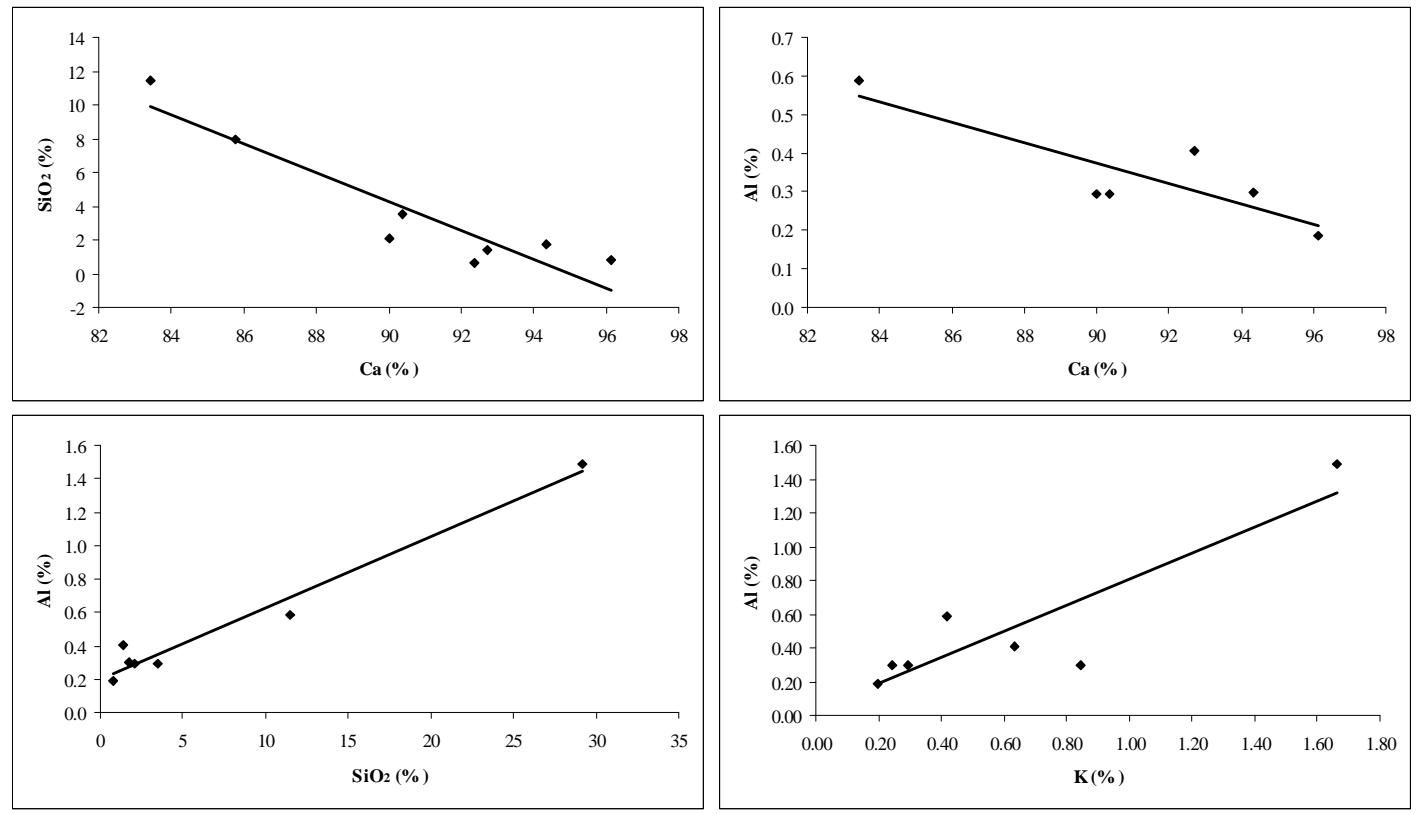

Fig. 5. Correlations between biogenic origin $(\mathrm{Ca})$ and continental origin $(\mathrm{Si}, \mathrm{Al}, \mathrm{K})$ chemical elements of the marine carbonate sediment samples of the Brazilian northeast continental shelf, REVIZEE Program (19952000).

The co-assimilation with carbonates, which can occur during the formation of algal carbonate accumulations, can remove chemical substances from the interstitial solutions of the mainly superficial inshore platform sediments, released by more intense fluxes of the interstitial waters in this zone (FREIRE 1985). However, interstitial adsorption in the biominerals of these organisms (or other extracellular points or non-metabolic components) seems to play no important role regarding Fe, probably due to its ability to act as an inhibitor of calcium carbonate precipitation (LUTZ et al., 1996; YASUSHI; YASUSHI 1986; WILSON et al., 2004; ARYAL et al., 2006, EHRLICH, 1996; MARCADAM; PARSON, 2004). Metals can be passively (bioabsorption) and actively (bio-accumulation) captured by algae (MORSE, 2003; JAHAN et al., 2004).

The growth of algae through the biological assimilation of carbon dioxide, mainly by photosynthesis and bio-mineralization, and the algae's ability to capture metals are well known and have been used for pollution control. Nevertheless, there is little information about the consequences of the exposure of algae to a metal rich medium (YAN, 1999; HAMDY, 2000; STIRK; VAN STADEN, 2002; SCHULTZ et al., 2004, WILSON et al., 2004; BUCUR; SASARAN, 2005).

Due to their high calcium carbonate content, ranging from 83 to $96 \%$, and the total absence of toxic

chemicals, the carbonate algae of the CE-RN continental platform show great potential for use for pharmacological and cosmetic purposes. However, in order to corroborate this preliminary geochemical statement, further chemical analysis of a larger number of sampling points of this huge deposit is required.

\section{Conclusions}

Considering the immense volume and biogeochemical characteristics, significant economic importance should be attributed to the coarse-grained marine deposits of the continental shelf within the legal domain of the States of Ceará and Rio Grande do Norte.

All the bioclastic samples analyzed, rich in calcium carbonate and free of metallic pollutants, indicate an extremely pure carbonate deposit, with great potentiality for various industrial purposes such as nutritive supplements in general, cosmetic components, $\mathrm{pH}$ correction of soils, etc. On the other hand, the calcium of marine biological sources is more easily absorbed than that of geological origin, which constitutes a positive environmental factor. Future sampling campaigns and geochemical analysis, covering the whole range of the deposits, will certainly provide the basis for a better understanding of these marine deposits and their economic usefulness. 


\section{ACKNOWLEDGEMENTS}

This study is part of the DCR project "Geochemical characterization of the carbonate sediments of the Continental Platform of the Ceará State and coastal banks, Brazil", supported by the Brazilian National Counsel of Technological and Scientific Development (CNPq) and Cearense Foundation for the support of Scientific and Technological Development (FUNCAP). The analyses were carried out at the Laboratory of Marine and Applied Geology (LGMA) of the Geology Department with the contribution of the Physics laboratory, both of the Federal University of Ceará (UFC).

\section{REFERENCES}

ARYAL, S.; BAHADUR, R. K. C.; BHATTARAI, S. R.; PRABUA, P.; KIM, H. Y. Immobilization of collagen on gold nanoparticles: preparation, characterization, and hydroxyapatite growth. J. Mater. Chem., v. 16, p. 4642-4648, 2006.

BUCUR, I. I.; SASARAN, E. Relationship between algae and environment: an Early Cretaceous case study, Trascau Mountains, Romania. Facies, v. 51: p. 274-286, 2005.

CALLIARI, L. J. ; CORREA, I. C. S. ; ASP, N. E. Inner shelf and beach seashell resources in Southern Brazil. In: MARTINS, L. R.; SANTANA, C. I. (Ed.). Non living resources of the southern Brazilian coastal zone and continental margin. Porto Alegre: Ponto Um:IG/UFRGS, 1999. 110 p.

COMISSÃO NACIONAL INDEPENDENTE SOBRE OS OCEANOS. Os usos dos oceanos no século 21 - A contribuição brasileira. Relatório final à Comissão Mundial Independente sobre os Oceanos, 1998. 133 p.

COUTINHO, P. N. Sedimentos carbonáticos da plataforma continental brasileira. Rev. Geol, p. 65-75, 1995.

COUTINHO, P. N. Levantamento do estado da arte da pesquisa dos recursos vivos marinhos do Brasil. Relatório do Programa REVIZEE (1995-2000), Oceanografia Geológica. Brasília, DF.: FEMAR/SECIRM/MMA, 2005. 138 p.

DE MELO, P. C.; FURTINI NETO, A. E. Avaliação do Lithothamnium como corretivo da acidez do solo e fonte de nutrientes para o feijoeiro. Ciênc. Agrotec., Lavras, v. 27, n. 3, p.508-519, 2003.

EHRLICH, H. L. Geomicrobiology. 3rd ed., rev. and expanded. New York: Marcel Dekker, 1996. 719 p.

FREIRE, G. S. S. Geologia marinha da plataforma continental do Estado do Ceará. 132 p. Tese (Mestrado em Geologia Marinha) - Centro de Tecnologia da Universidade Federal de Pernambuco, Recife, 1985.

FREIRE, G. S. S.; CAVALCANTI, V. M. M.; MAIA, L. P.; LIMA, S. F. Classificação dos sedimentos da plataforma continental do Estado do Ceará. In: SIMPÓSIO DE GEOLOGIA DO NORDESTE, 17. 1997, Fortaleza. Anais... Fortaleza: UFC, 1997, p. 209-211.

FREIRE, G. S. S.; CAVALCANTI, V. M. M. A cobertura quaternária da plataforma continental do Estado do Ceará. Brasilia, DF: DNPM , 1998. v. 1, p. 42.
FREIRE, G. S. S ; LIMA, S.; MAIA, L. P.; LACERDA, L. D. Geochemistry of continental shelf sediments of the Ceará coast, NE Brazil. In: LACERDA, L. D.; SANTELLI, R. E.; DUURSMA, E. K.; ABRÃO, J. J (Ed.). Facets of environmental Geochemistry in tropical and subtropical environments. Berlin: Springer Verlag, 2004. p. 365-378.

HAMDY, A. A. Biosorption of heavy metals by marine algae. J. curr. Microbiol., v. 41, p. 232-238. 2000.

JAHAN, K.; MOSTO, P.; MATTSON, C.; FREY, E.; DERCHAK, L. Waste management and the environment II. In: INTERNATIONAL CONFERENCE ON WASTE MANAGEMENT AND THE ENVIRONMENT, 2., 2004, Rhodes. Resumé... UK: Wessex Institute of Technology, 2004. p. 223-232.

LACERDA, L. D.; MARINS, R. V. Geoquímica de sedimentos e o monitoramento de metais na plataforma continental nordeste oriental do Brasil. Geochem. Bras., v. 20 , n. 1, p. 123-135, 2006.

LAMAS, F.; IRIGARAY, C.; OTEO, C.; CHACON, J. Selection of the most appropriate method to determine the carbonate content for engineering purposes with particular regard to marls. Engineer. geol., v. 81, p. 3241, 2005.

LARSONNEUR, C. La cartographie des dépôt meubles sur le plateau continental français: méthode mise au point et utilisée en Manche. J. Rech. Oceanogr., v. 2, p. 34-39, 1977.

LUTZ, V. A.; SATHYENDRANATH, S.; HEAD, E. J. H. Absorption coefficient of phytoplankton: regional variations in the North Atlantic. Mar. Ecol. Prog. Ser., v. 135 , p. 197-213, 1996

MARCADAM, J.; PARSONS, S. A. Calcium carbonate scale control, effect of material and inhibitors. Water Sci. Technol., v. 49, n. 2, p. 153-159, 2004.

MONT'ALVERNE, A.; COUTINHO, P. N. Províncias sedimentares na plataforma continental de Pernambuco. In: CONGRESSO BRASILEIRO DE GEOLOGIA, 32., 1982, Salvador. Anais...Salvador: UFBA, 1982. p. 1524-1430.

MORSE, J. W. Formation and diagenesis of carbonate sediments. In: MACKENZIE, F. T. (Ed.). Sediments, diagenesis and sedimentary rocks, treatise on Geochemistry 7, 2003. p. 67-86.

POZEBON, D.; LIMA, E. C.; MAIA, S. M.; FACHELJ, M. G. Heavy metals contribution of non-aqueous fluids used in offshore oil drilling. Fuel, v. 84, p, 53-61, 2005.

REDE APL MINERAL. Arranjos produtivos locais de base mineral. Setor Mineral do Estado do Ceará. GUERRA, ELZIVIR AZEVEDO (Coord.). Brasília, DF: Ministério de Ciência e Tecnologia - MCT, Secretaria de Desenvolvimento Tecnológico e Inovação - SETEC, Coordenação-Geral de Tecnologias Setoriais -CGTS, Coordenação de Programas Mobilizadores (Recursos Minerais). Location: <http://www.redeaplmineral.org.br/>. Accessed: 2008.

REZENDE, C. E.; LACERDA, L. D.; OVALLE, A. R.C.; SOUZA, C. M. M.; GOBO, A. A. R.; SANTOS, D. O. The effect of an oil drilling operation on the trace metal distribution in bottom sediments from the Brazilian continental platform. Mar. Pollut. Bull., v. 44, p. 680684, 2002. 
SALES, H. B.; MELO, L. M.; SAMPAIO, R. L.; FREIRE, G. S. S. Otimização de abertura de algas calcárias da plataforma continental do Ceará. In: CONGRESSO BRASILEIRO DE QUÍMICA, 33., 1994, Fortaleza. Anais... Fortaleza: UFC, 1993. p. 3-6.

SCHULZ, K. G.; ZONDERVAN, I.; GERRINGA， L; TIMMERMANS, K. R.; VELDHUIS, M. J.; RIEBESELL, U. Effect of trace metal availability on coccolithophorid calcification. Nature, Lond., v. 430, n. 7000, p. 673-676, 2004.

SHEPARD, F. P. Nomenclature based on sand-silt-clay rations. J. sediment. Petrol., v. 24, n. 3, p. 151-158, 1954.

STEINHAUER, M.; CRECELIUS, E.; STEINHAUE, W. Temporal and spatial changes in the concentrations of hydrocarbons and trace metals in the vicinity of an off shore oil-production platform. Mar. environ. Res., v. 37, p. 129-163, 1994.
STIRK, W. A.; VAN STADEN, J. Desorption of cadmium and the reuse of brown seaweed derived products as biosorbents. Botanica mar., v. 45, n. 1, p. 9-16, 2002.

YAN, X. Assessment of calcareous alga Corallina pilulifera as elemental provider. Biom. Bioenerg., v. 16, p. 357360, 1999.

YASUSHI, O.; YASUSHI, K. Coprecipitation of alkali metal ions with calcium carbonate. Geochim. cosmochim. Acta, v. 50, n. 1, p. 49-58, 1986.

WILSON, S.; BLAKE, C.; BERGES, J. A.; MAGGS, C. A. Environmental tolerances of free-living coralline algae (maerl): implications for European marine conservation. Biol. Conserv., v. 120, p. 279-289, 2004.

(Manuscript received 03 June 2009; revised 15 December 2009; accepted 09 March 2010) 